\title{
Equilibrium, Kinetic and Thermodynamic Studies of Dyes in Aqueous Solution onto Iron Nanocomposite Stabilized by Irvingia gabonensis Leaf Extract
}

\author{
*ADOWEI, P; EBONG, SE; OBUZOR, GU \\ Department of Pure and Industrial Chemistry, Faculty of Science, University of Port Harcourt, Choba, Nigeria \\ *Corresponding Author Email: Pereware.adowei@uniport.edu.ng
}

\begin{abstract}
Elimination of dyes in contaminated water or wastewater has become a universal challenge because of their colouration, toxicity, mutagenicity and carcinogenicity when discharged into the recipient environment without treatment and several technologies have been developed to deal with this problem. This paper reports the potential of exploring the use and comparison of conventional iron zero-valent (nZVI) nanoparticle and Irvingia gabonensis stabilized iron nanocomposite (Ig-nZVI) for the elimination of methyl red (MR) and methyl orange (MO) dyes in aqueous solution under effect of different experimental conditions of adsorbent dosage, initial dye concentrations, $\mathrm{pH}$, contact time and temperature. Data obtained show an increase in percent dye elimination as the amount of adsorbent increased. The optimal removal of MR and MO occurred in $<60 \mathrm{~min}$ of the start of each experimentation, obtained at a maximum $\mathrm{pH}$ of 5.1 at $98.5 \%$ and $80.6 \%$ for adsorbent dosage of $0.3 \mathrm{~g} / 50 \mathrm{~mL}$ and $20 \mathrm{mg} / \mathrm{L}$ initial dye concentration at temperature of $27^{\circ} \mathrm{C}$. The experimental data fitted the Lamgmuir isotherm with maximum adsorption capacity $\left(\mathrm{q}_{\max }\right)$ of $166.7 \mathrm{mg} / \mathrm{g}$ (Ig-nZVI) and $83.35 \mathrm{mg} / \mathrm{g}$ (nZVI) for MR while $128.21 \mathrm{mg} / \mathrm{g}$ (Ig-nZVI) and $40.02 .5 \mathrm{mg} / \mathrm{g}$ (nZVI) were obtained for MO. Kinetics studies showed that the removal of MR and MO fitted the pseudo second-order model. The adsorption of MR and MO were endothermic and spontaneous with enthalpy values of $3.39 \mathrm{~kJ} / \mathrm{mol}$ (Ig-nZVI) and $776.26 \mathrm{~kJ} / \mathrm{mol}$ (nZVI) and standard Gibbs free energy values of $-5.95 \mathrm{~kJ} / \mathrm{mol}$ (Ig-nZVI) and $-12.00 \mathrm{~kJ} / \mathrm{mol}$ (nZVI). Thermodynamic studies $(\Delta G<0, \Delta H<0, \Delta S>0)$ implied a spontaneous and exothermic process in nature. The adsorption of MO was endothermic and spontaneous with enthalpy values of $31.70 \mathrm{~kJ} / \mathrm{mol}$ (Ig-nZVI) and $20.91 \mathrm{~kJ} / \mathrm{mol}$ (nZVI) and standard Gibbs free energy values of $-5.92 \mathrm{~kJ} / \mathrm{mol}$ and $-7.07 \mathrm{~kJ} / \mathrm{mol}$ for Ig-nZVI and nZVI respectively. Adsorbent produced from leaf extracts of African mango tree (Irvingia gabonensis) and stabilized by iron oxide could be an attractive option for elimination of dye from industrial effluents.
\end{abstract}

DOI: https://dx.doi.org/10.4314/jasem.v25i12.12

Copyright: Copyright $\odot 2021$ Adowei et al. This is an open access article (https://pkp.sfu.ca/ojs/) distributed under the Creative Commons Attribution License (CCL), which permits unrestricted use, distribution, and reproduction in any medium, provided the original work is properly cited.

Dates: Received: 22 August 2021; Revised: 17 September 2021; Accepted: 06 October 2021

Keywords: African bush mango, nano-composite, Irvingia gabonensis, methyl red, Methyl orange

Dyes are principally used in the production of consumer products such as paints, textiles, printing inks, paper, and plastics (Kant, 2012). Rapid industrialization and urban development, have resulted in the generation of large quantities of aqueous effluents, many of which contain high levels of harmful pollutants such as organic dyes (Vijayaraghavan and Yun, 2008, Xu et al., 2013). They pollute not only the environment but also pass through the entire food chain, leading to biomagnifications (Lin et al., 2004; Gürses et al., 2006; Li, 2010 and Gil et al., 2011). Almost every industry uses dyes for their products. Dye industry effluents constitute one of the most challenging wastewaters to be treated not only for their high chemical oxygen demand (COD), biological oxygen demands (BOD) and reduction in dissolved oxygen (DO) of the water bodies but also for the colour they impart on these water bodies (Zawani et al., 2009). Over the years, many physical, chemical and biological approaches have been employed for the evacuation of dyes from wastewater namely coagulation (Szygułaa et al., 2009), precipitation (Zhu et al., 2007), separation through membranes (Alventosa-deLara et al., 2012), electrolysis (Wang, 2009), photolysis (Guo et al., 2006), extraction (Abbassiana et al., 2015), oxidation (Gomes et al., 2012), biological treatments (Popli and Patel, 2015), and adsorption (Shaibu et al., 2014) nevertheless with some setbacks (Wang et al., 2010). Several popular low-cost adsorbents, including natural materials, biologically derived adsorbents, and waste materials from agricultural industries have also been used by some researchers (Namasivayam and Yamuna, 1992; Horsfall and Spiff (2005), Horsfall et al (2005), Adowei et al (2016), Ebong et al., (2020), Tarawouu et al (2007); Namasivayam and Arasi 1997). The lowcost adsorbents are bedevilled with bulkiness in nature, slow adsorption kinetics, low capacity, disposal problems and re-generation, hence some authors have used activated carbon, hydrogen peroxide $\left(\mathrm{H}_{2} \mathrm{O}_{2}\right)$, sodium hyperchlorite and other 
chemical agents for the textile industries effluents (Preethi et al., 2006, Meshko et al., 2001; Chen et al., 2001, Purkait et al., 2007; Chen et al., 2011). Consequently, adsorbents such as nanocomposites (Adeyemo et al., 2017) and zerovalent metals (Ponder et al., 2000; Lin et al., 2005; Xiong et al., 2007; Wu et al., 2009; Xu et al., 2010; Wang et al., 2010; Liu et al., 2010; Liu and Zhang, 2010) have become important for the removal of heavy metal ions, dyes and other pollutants from aqueous solution.

Recently, plant extracts are used to reduce metal ions to nanoparticles in a single-step green synthesis process (Saif et al., 2016). This biogenic reduction of metal ion to base metal is quite fast, readily conducted at room temperature and pressure, and easily scaled up. Synthesis mediated by plant extracts is environmentally benevolent. The reducing agents involved include the various water soluble plant metabolites (e.g. alkaloids, phenolic compounds, terpenoids) and co-enzymes. Textile effluents containing dyes and other organic compounds require fast treatment due to their toxic health and environmental effects (Sayyad et al., 2012; Siskova et al., 2013). Irvingia gabonensis (Aubry-LeComte er O'Rorke) Bail (Irvingiaceae) commonly called wild mango or African bush mango or ogbono is a plant tree that occurs freely in Nigeria and produces an edible fresh mango-like fruit whose seed is used in the preparation viscous soup (Okogun, 2002; Abdulrahman et al., 2004). Irvingia gabonensis has two fruiting seasons: from April to July and from September to October and produces huge amount of leaf droppings as waste. The fruit (Okogun, 2002), seed (Ngodi et al., 2005), stem bark (Mgbemena et al., 2019) and root (Oben, 2011) has been investigated for various uses other than food, however, studies on the leaf is scanty. Due to the paucity of data on the leaf, this study explored the potential of employing the use and compare convention iron zerovalent (nZVI) nanoparticle and Irvingia gabonensis stabilized iron (Ig-nZVI) nanocomposites for elimination of methyl red (MR) and methyl orange (MO) in aqueous solution.

\section{MATERIALS AND METHODS}

Dye Used: The dyes used for this work are methyl red (MR) and methyl orange (MO) presented in figure 1a and $b$ respectively. Other chemical reagents used were of analytical grade and acquired from representatives of Merck and Aldrich.
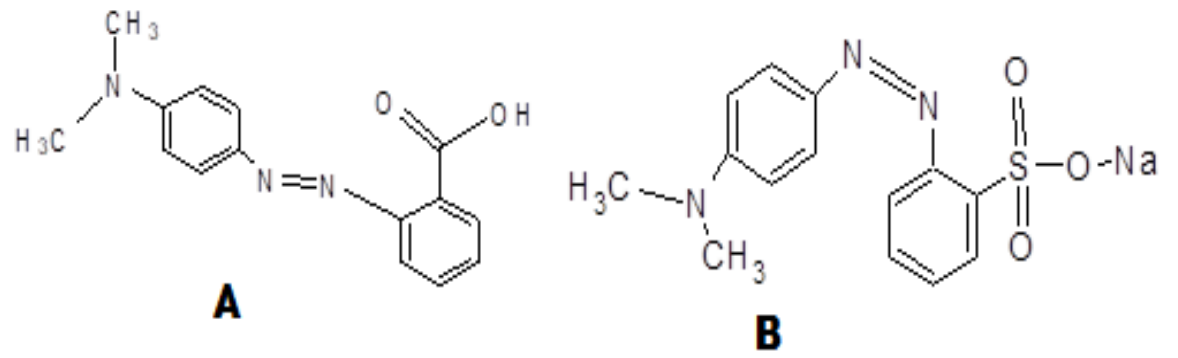

Fig 1: Structure of Methyl Red [A] and Methyl Orange [B]

Sample collection: Fresh leaves of African bush mango (Irvingia gabonensis) were collected from Delta Park University of Port Harcourt Rivers State, Nigeria. Taxonomical identification and authentication were carried out at the University of Port Harcourt Herbarium.

Sample Preparation and Synthesis: Fresh leaves were plucked from African bush mango (Irvingia gabonensis) tree and washed several times with tap water and finally two times with distilled water to remove dirt, bird droppings and other impurities. The washed leaves were sun dried for 5 hours to remove residual moisture. Dried leaves were grounded to powdery form and kept for further use as samples. The detailed procedure for the aqueous extraction, synthesis of zerovalent iron nanoparticles and preparation of African bush mango leaf extract stabilized by iron oxide has been published elsewhere (Ebong et al., 2020).

Preparation of Calibration Curves for the Dyes (MR and MO): Preparation of Methyl Red (MR) and Methyl Orange (MO) Dye Solution: A stock solution of $1,000 \mathrm{mg} \mathrm{L}^{-1}$ was prepared by dissolving an appropriate $250 \mathrm{mg}$ of MR and MO in separate 250 $\mathrm{mL}$ double-distilled water. Different concentrations of $5,15,25,45$, and $55 \mathrm{mg} \mathrm{L}^{-1}$ of dye were prepared from the stock solution. The sample concentrations were measured using a double beam UV-Vis spectrophotometer (U-2910, Hitachi, Tokyo, Japan) at room temperature $\left(27^{\circ} \mathrm{C} \pm 2^{\circ} \mathrm{C}\right)$ at their maximum absorption wavelengths.

Batch Dye Elimination Studies: Effect of adsorbent dosage on adsorption: To $10 \mathrm{ml}$ of dye (MR and MO) with $20 \mathrm{mg} / \mathrm{L}$ concentration in two identical $100 \mathrm{ml}$ 
conical flask was added $0.02 \mathrm{~g} 0.04 \mathrm{~g}, 0.06 \mathrm{~g}, 0.08 \mathrm{~g}$, $0.1 \mathrm{~g}, 0.2 \mathrm{~g}$ and $0.3 \mathrm{~g}$ of Ig-nZVI and nZVI respectively and gently agitated for complete dispersion of the adsorbents with dye solutions and kept for 30mins. The reaction flask was again agitated after $30 \mathrm{mins}$ and filtered through Whatman filter paper number 1 . The filtrates were stored in sterile plastic containers for determination of the final dye concentration using UV Visible spectrometer.

Effect of initial concentration on adsorption: The influence of initial dye concentration on adsorption was studied at room temperature. The concentration of each dye solution was varied from: 5, 10, 15, 20 and $25 \mathrm{mg} / \mathrm{l}$ respectively. A measured mass of $0.3 \mathrm{~g}$ of nZVI and Ig-nZVI was added to each initial concentration of dye solution. The mixture was agitated and equilibrated for 30 mins. The mixture was filtered and the filtrate collected into sterile plastic container for the determination of the final dye concentration using UV-Visible spectrometer.

Effect of pH on adsorption: The dye solutions with 20 $\mathrm{mg} / \mathrm{L}$ concentration (MR and MO) were pre-adjusted to $\mathrm{pH} 3,5,7,9$ and 11 with the addition of either $0.1 \mathrm{M}$ $\mathrm{HCl}$ or $1 \mathrm{M} \mathrm{NaOH}$ solutions. To $10 \mathrm{ml}$ of dye solution at the different $\mathrm{pH}$, in two identical $100 \mathrm{ml}$ conical flask was added $0.3 \mathrm{~g}$ of Ig-nZVI and nZVI respectively and gently agitated for complete mixture of the adsorbents with the dye solutions and kept for $30 \mathrm{~min}$, thereafter, the mixture was agitated again and filtered with Whatman filter paper number 1 and the filtrates were stored in sterile plastic containers for UV-visible analysis.

Effect of time on adsorption: To $10 \mathrm{ml}$ of dye with 20 $\mathrm{mg} / \mathrm{L}$ concentration solution in two identical $100 \mathrm{ml}$ conical flask, was added $0.3 \mathrm{~g}$ of Ig-nZVI and nZVI respectively and gently agitated for complete mixture of the adsorbents with the dye solutions at room temperature $\left(27^{\circ} \mathrm{C}\right)$ and agitated again for $15 \mathrm{~min}, 30$ min, $45 \mathrm{~min}, 60 \mathrm{~min}$, and $75 \mathrm{~min}$. At the end of each agitation time interval, the mixture was filtered using Whatman filter paper number 1 and the filtrate stored in sterile plastic containers for UV-visible spectroscopic analysis.

Effect of temperature on adsorption: To $10 \mathrm{ml}$ of dye with $20 \mathrm{mg} / \mathrm{L}$ concentration in two identical $100 \mathrm{ml}$ conical flask was added $0.3 \mathrm{~g}$ of Ig-nZVI and nZVI respectively and gently agitated for complete mixture of the adsorbents with the dye solutions and transferred to a thermostat water bath which was preset at $30^{\circ} \mathrm{C}, 45^{\circ} \mathrm{C}, 60^{\circ} \mathrm{C}, 75^{\circ} \mathrm{C}$ and $90^{\circ} \mathrm{C}$ for $30 \mathrm{~min}$. The reaction flask was removed from the water bath and agitated and filtered through Whatman filter paper number 1 . The filtrates were stored in sterile plastic containers for UV-visible analysis.

Analysis and Mass Balance Calculation: The concentration of dye $(\mathrm{mg} / \mathrm{L})$ in the solution was measured by direct UV-visible spectrophotometric method using Genesis 20 Thermo Scientific at optimum wavelength. All the experiments were duplicated, and only the mean values were reported. The amount of dye eliminated at equilibrium by the nZVI and Ig-nZVI, qe (mg/g), were calculated by the mass balance relationship in equation 1 :

$$
\mathrm{q}_{e}=\frac{\mathrm{C}_{\mathrm{O}}-\mathrm{C}_{\mathrm{e}}}{V} x \mathrm{~W} \quad 1
$$

Where $\mathrm{C}_{\mathrm{O}}$ and $\mathrm{C}_{\mathrm{e}}(\mathrm{mg} / \mathrm{L})$ are the initial and equilibrium liquid-phase concentrations of dye, respectively, $\mathrm{V}$ is the volume of the solution ( $\mathrm{L})$, and $\mathrm{W}$ is the weight of nanocomposite used $(\mathrm{g})$.

The percentage of dye eliminated from solution were calculated according to equation 2 .

$$
\% \text { Elimination }=\frac{\mathrm{C}_{\mathrm{O}}-\mathrm{C}_{\mathrm{e}}}{\mathrm{C}_{\mathrm{o}}} \times 100
$$

Where $\mathrm{C}_{\mathrm{o}}(\mathrm{mg} / \mathrm{L})$ is the initial dye concentration, $\mathrm{C}_{\mathrm{e}}$ $(\mathrm{mg} / \mathrm{L})$ is the equilibrium concentration

Equilibrium Isotherm Studies: Equilibrium isotherm studies were obtained from the different concentrations of MR and MO measured at room temperature under the experimental procedures for the effect of concentration.

The linearized Langmuir and Freundlich equilibrium isotherm model equations were used to describe the experimental data.

Langmuir Equilibrium Isotherm Model Equation: The linear form of the Langmuir equation used is presented in equation 3 :

$$
\frac{\mathrm{C}_{\mathrm{e}}}{\mathrm{q}_{\mathrm{e}}}=\frac{1}{\mathrm{~K}_{\mathrm{L}} \mathrm{q}_{\mathrm{m}}}+\frac{1}{\mathrm{Q}_{\mathrm{m}}} C_{e} \quad 3
$$

Where $q_{m}$ is the maximum monolayer capacity of the adsorbent $(\mathrm{mg} / \mathrm{g}), K_{L}$ is the adsorption equilibrium constant (L/mg).

A plot of $\frac{C_{e}}{q_{e}}$ versus $C_{e}$ is expected to give a slope of $\frac{1}{q_{m}}$ and intercept of $\frac{1}{\mathrm{~K}_{\mathrm{L}} \mathrm{qm}_{\mathrm{m}}}$; which will be used to evaluate the maximum monolayer capacity $\left(q_{m}\right)$ and the adsorption equilibrium constant $\left(K_{L}\right)$. 
Freundlich Equilibrium Isotherm Model Equation: The linear Freundlich isotherm equation employed for the evaluation of the experimental data is given in equation 4.

$$
\log \mathrm{q}_{\mathrm{e}}=\log \mathrm{K}_{\mathrm{F}}+\frac{1}{\mathrm{n}} \log \mathrm{C}_{\mathrm{e}} \quad 4
$$

Where $\mathrm{K}_{\mathrm{F}}$ is the Freundlich adsorption or distribution coefficient and represents quantity of dye adsorbed onto the adsorbent for unit equilibrium concentration and $\frac{1}{n}$ is the adsorption intensity of dye onto the adsorbent or surface heterogenecity, becoming more heterogeneous as its value gets closer to zero

The applicability of the Freundlich adsorption isotherm was also analyzed using the same set of experimental data, by plotting $\log \mathrm{q}_{\mathrm{e}} \mathrm{vs} \log \mathrm{C}_{\mathrm{e}}$.

Kinetics Studies: Kinetic studies were obtained from the data for the effect of contact time of dye measured at room temperature. The kinetics of dye (MR and MO) onto nZVI and Ig-nZVI were analyzed using pseudo-first-order and pseudo-second order kinetic models.

Pseudo-first-order kinetic model equation: The linearized form of the Lagergren pseudo-first-order kinetic model equation used is presented in equation 5.

$$
\log \left(q_{e}-q_{t}\right)=\log \left(q_{q}\right)-\frac{k_{1}}{2.303} t \quad 5
$$

Where $q_{e}$ and $q_{t}$ are the adsorption capacity at equilibrium and at time, $\mathrm{t}$ respectively $(\mathrm{mg} / \mathrm{g}), k_{1}$ is the rate constant of pseudo-first order adsorption ( $\mathrm{L} / \mathrm{min})$.

A plot of $\log \left(\mathrm{q}_{\mathrm{e}}-\mathrm{q}_{\mathrm{t}}\right)$ versus $\mathrm{t}$ will be used to evaluate the Langergren constants.

Pseudo-second-order kinetic model equation: The linear form of the pseudo-second-order equation (6) used is presented as

$$
\frac{1}{q_{t}}=\frac{1}{k_{2} q_{e}^{2}}+\frac{1}{q_{e}} t \quad 6
$$

Where ${ }_{\mathrm{k} 2}(\mathrm{~g} / \mathrm{mg}$ min) is the second order rate constant of the adsorption process

The linear plots were made using $\frac{1}{q_{t}}$ versus $\mathrm{t}$

Thermodynamic Studies: Thermodynamic parameters were computed from data obtained by measurement of temperature varied from 303 to $353 \mathrm{~K}$. Thermodynamic parameters such as the thermodynamic equilibrium constant, $\mathrm{K}_{\mathrm{e}}$ (Eqn. 7), change in standard Gibbs free energy, $\Delta G^{o}$ (Eqn. 8), change in standard enthalpy, $\Delta H^{o}$ (Eqn. 9), change in standard entropy, $\Delta S^{o}$ (Eqn. 10), and activation energy, $E_{a}$ (Eqn. 11), were computed using the following equations:

$$
\begin{array}{rl}
\mathrm{K}_{\mathrm{e}} & =\frac{\mathrm{q}_{\mathrm{e}}}{\mathrm{C}_{\mathrm{e}}} \\
\Delta \mathrm{G}^{\mathrm{O}}=-\mathrm{RT} \ln \mathrm{K}_{\mathrm{e}} & 8 \\
\mathrm{G}^{\mathrm{O}}=\mathrm{H}^{\mathrm{O}}-\mathrm{T} \Delta \mathrm{S}^{\mathrm{O}} & 9 \\
\ln \mathrm{K}_{\mathrm{e}}=\frac{\Delta \mathrm{S}^{\mathrm{O}}}{\mathrm{RT}}-\frac{\Delta \mathrm{H}^{\mathrm{O}}}{\mathrm{RT}} & 10 \\
\ln \mathrm{K}_{\mathrm{e}}=\ln A-\frac{E_{a}}{\mathrm{RT}} & 11
\end{array}
$$

\section{RESULTS AND DISCUSSION}

The response of absorbance to different concentrations of MR and MO dyes were plotted (Fig 2a and b). The absorbance was measured at different concentrations of dye MR and MO. The linear portion of the calibration curve is fit with a line. The equation for MR is $y=0.0137 x+0.1564$ with $R^{2}$ value of 0.9955 and that of $\mathrm{MO}$ is $\mathrm{y}=0.0336 \mathrm{x}+0.1056$ with $\mathrm{R}^{2}$ value of 0.9915 . The equations were found to describe the relationship between absorbance and concentrations with correlation coefficients $>0.99$.
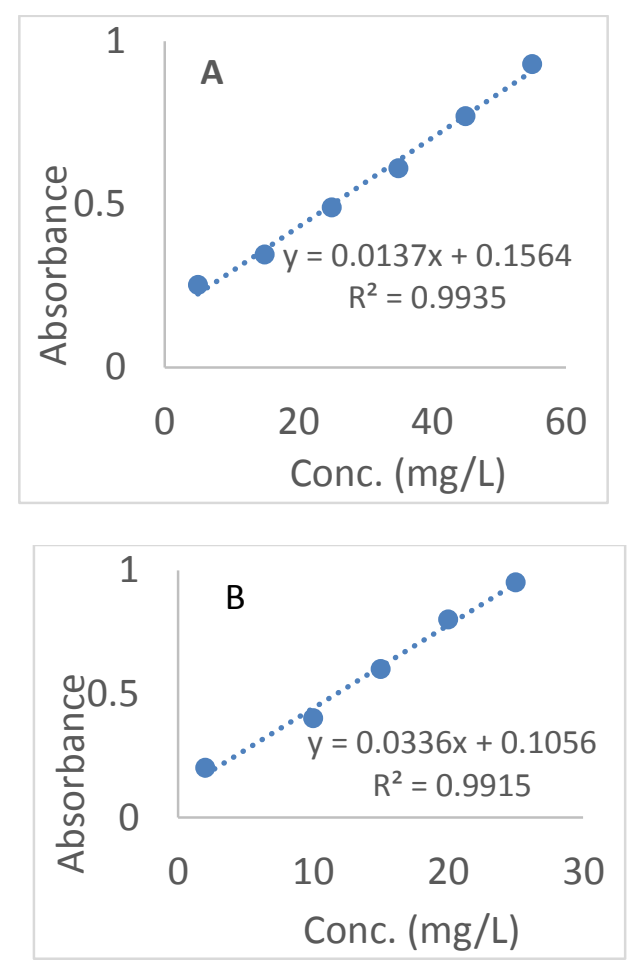

Fig 2. Calibration curve for methyl red (A) and methyl orange (B) 
Effect of Adsorbent Dosage: According to Figure 3, the rate of elimination of both dyes increased with increase in the adsorbent (Ig-nZVI and nZVI) dose. At a dose of $0.02 \mathrm{~g}$, it was observed that $35.70 \%$ and $26.1 \%$ of MR was eliminated by Ig-nZVI and nZVI respectively while that of $\mathrm{MO}$ were $27.33 \%$ and $33.13 \%$ respectively. Subsequent doses of $0.04 \mathrm{~g}$, $0.06 \mathrm{~g}, 0.08 \mathrm{~g}$ and $0.1 \mathrm{~g}$ correspondingly resulted in $48.10 \%, 71.40 \%, 88.61 \%$ and $94.17 \%$ elimination of MR by Ig-nZVI while the percentage elimination by nZVI occurred at $40.56 \%, 61.80 \%, 82.73 \%$ and $90.73 \%$ respectively. Results obtained for MO elimination showed that at doses of $0.04 \mathrm{~g}, 0.06 \mathrm{~g}$, $0.08 \mathrm{~g}$ and $0.1 \mathrm{~g}$, the percentage elimination increased to $57.17 \%, 78.10 \%, 82.2 \%$ and $89.00 \%$ for Ig-nZVI and $54.60 \%, 77.26 \%, 82.50 \%$ and $87.93 \%$ for nZVI respectively. The increase in adsorption with increase in adsorbent dose occurred as a result of increase in the surface area available for dye molecules to adsorb (Dada et al., 2015). The data showed that the percent elimination becomes constant for immediately after $0.1 \mathrm{~g}$ adsorbent dose up to $0.3 \mathrm{~g}$. Hence, the other experments were conducted using an adsorbent dose of $0.3 \mathrm{~g}$.

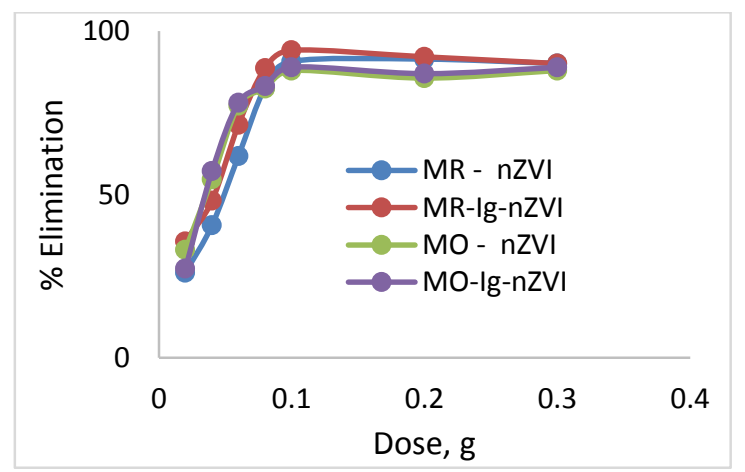

Fig 3: Effect of Adsorbent Dose on elimination of $M R$ and $M O$ with Ig-nZVI and nZVI

Effect of Initial Dye Concentration: The percentage elimination of MR and MO by both adsorbents decreased with an increase in initial dye concentration as shown in Figure 4. The elimination rates of MR by Ig-nZVI and nZVI were $98.5 \%$ and $80.6 \%$ respectively when the initial concentration of MR was $5 \mathrm{mg} / \mathrm{L}$ and its elimination percentage reduced to $71.1 \%$ as the initial concentration was increased to 10 $\mathrm{mg} / \mathrm{L}$. When the initial concentration was kept at $25 \mathrm{mg} / \mathrm{L}$, the elimination rate for both Ig-nZVI and nZVI dropped to $22.23 \%$ and $20.83 \%$. In the case of MO, similar trend was observed; at initial concentration of $5 \mathrm{mg} / \mathrm{L}, 80.63 \%$ and $74.10 \%$ of $\mathrm{MO}$ was eliminated by both Ig-nZVI and nZVI. On increasing the initial concentration to $10 \mathrm{mg} / \mathrm{L}$, percentage elimination dropped to $51.60 \%$ and
$55.16 \%$ for Ig-nZVI and nZVI respectively. In addition, when the initial concentration was kept at $25 \mathrm{mg} / \mathrm{L}$, the elimination rate for both Ig-nZVI and nZVI dropped to $27.00 \%$ and $28.76 \%$. The decrease in the elimination of both dyes in the aqueous media could be ascribed to a fixed amount $(0.03 \mathrm{~g})$ of both adsorbents (Ig-nZVI and nZVI) with restricted adsorption sites which gets easily saturated, consequently, leading to a decrease in percentage elimination of both dyes corresponding to increasing initial concentration of both dyes. This agrees with the result reported by Siskova et al. (2013).

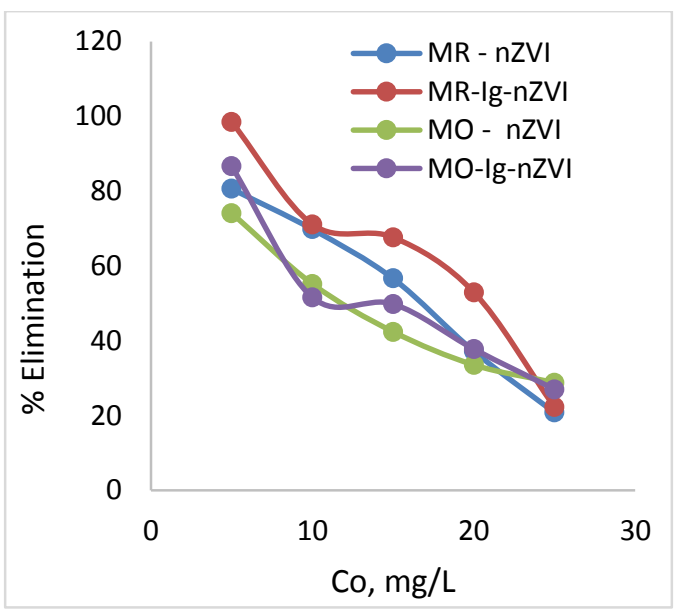

Fig 4: Effect of Initial Concentration on elimination of MR and MO with Ig-nZVI and nZVI

Effect of Time: At an initial contact time of $20 \mathrm{~min}$, elimination efficiency of Ig-nZVI and nZVI for MR was fast with percentage elimination of $48.97 \%$ and $44.15 \%$. A similar trend was observed for MO, with percentage elimination by Ig-nZVI and nZVI at $33.5 \%$ and $40.7 \%$ respectively. Percentage elimination of MR at contact time $30-45 \mathrm{~min}$ for Ig-nZVI and nZVI increased from $61.40-72.93 \%$ and $51.37-67.43 \%$ respectively. For MO, an increase in percentage elimination was also observed at the same contact time range with values of $56.80-69.00 \%$ for Ig-nZVI and 42.50-52.53\% for nZVI. After $60 \mathrm{~min}$, the elimination percentage of MR by Ig-nZVI and nZVI increased to $94.2 \%$ and $78.61 \%$ and that of MO by both adsorbents (Ig-nZVI and nZVI) also increased to $79.77 \%$ and $59.60 \%$. However, on increasing the contact time to $75 \mathrm{~min}$, there was no significant elimination of both dyes; the percentage elimination obtained for MR was $96.43 \%$ and $80.75 \%$ for Ig-nZVI and nZVI respectively while that of MO was $81.5 \%$ and $61.70 \%$ for Ig-nZVI and nZVI respectively (Figure 5). This result could be attributed to the fact that at the initial stage, there were large numbers of unoccupied sites on the surface of the adsorbents (Ig-nZVI and nZVI) for adsorption. But as contact time increased, the 
unoccupied sites became saturated, which lead to slow pore diffusion of the MR and MO molecules onto the adsorbents (Ig-nZVI and nZVI) and repulsion between the solid molecules and the bulk phases which is similar to the result of Karima et al. (2010).

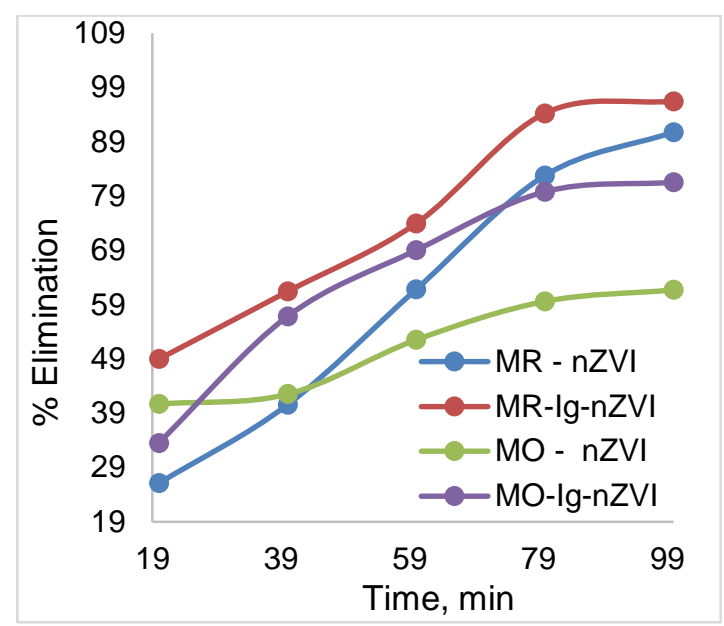

Fig 5: Effect of Contact Time on elimination of MR and MO with Ig-nZVI and nZVI

Effect of $p H$ : During the adsorption process, functional groups, surface charges, degree of ionization and solubility of adsorbent are important factors which are influenced by $\mathrm{pH}$ of the aqueous solution. Results obtained for the elimination of dyes at various $\mathrm{pH}$ (Figure 6) increased from $\mathrm{pH} 2$ to a maximum at about $\mathrm{pH} 5.1$ and gradually decreased to $\mathrm{pH} 11$. Percentage elimination of $\mathrm{MR}$ at $\mathrm{pH} 11,9,7,5$ and 3 were $37.3 \%$, $41.5 \%, 50.3 \%, 80.33 \%$ and 54.6 respectively for IgnZVI and $54.7 \%, 56.4 \%, 57.3 \%, 64.4 \%$ and $59.4 \%$ respectively for nZVI. This is because at lower $\mathrm{pH}$ there were greater number of hydrogen ions present and thus, the degradation increased. The iron particles donate two electrons to the $\mathrm{H}^{+}$ions converting them into atoms which in turn attacks the dye particles present in the wastewater, breaking them down to amines and rendering them colorless (Chatterjee et al., 2010). Likewise, the percentage elimination of MO from the aqueous medium increased with decreasing $\mathrm{pH}$. At $\mathrm{pH} 5$, the elimination efficiency increased from $93.83 \%$ to $95.63 \%$ and from $62.36 \%$ to $86.86 \%$ for IgnZVI and nZVI respectively. Whereas increasing the $\mathrm{pH}$ of dye solution to 7.0, 9.0 and 11 with the same amount of adsorbents $(0.03 \mathrm{~g})$ at $27^{\circ} \mathrm{C}$ and $10 \mathrm{~min}$ contact time a decrease in the elimination of both dyes was observed with values of $63.33 \%, 58.30 \%$ and $56.90 \%$ respectively for Ig-nZVI and $53.36 \%, 51.86 \%$ and $51.60 \%$ respectively for nZVI. The low adsorption capacity at alkaline $\mathrm{pH}$ may be attributed to a decrease in reducing power of nanoparticles due to covering of nanoparticle with corrosion products; there is also a change in the charge of ZVI surface from positive to negative at alkaline $\mathrm{pH}$ which causes a repulsion force between the dye and nanoparticles (Phenrat et al., 2007).

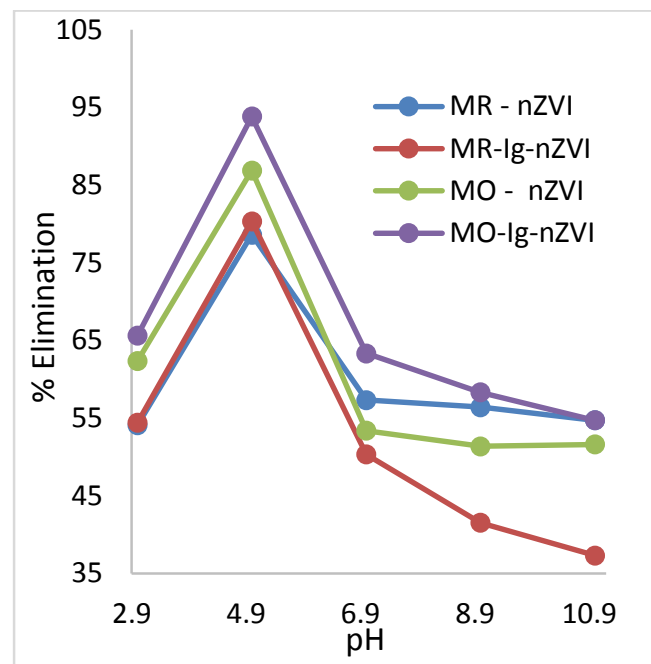

Fig 6: Effect of $\mathrm{pH}$ on elimination of MR and $\mathrm{MO}$ with Ig-nZVI and nZVI

Effect of Temperature: The elimination of MR and MO by nanoparticles (Ig-nZVI and nZVI) from aqueous media was controlled by temperature of the dye solutions. The result as shown in Figure 7 was evident that dye (MR and MO) elimination increased with increase in the temperature of the reaction. The elimination of MR by adsorbents (Ig-nZVI and nZVI) was found to increase from $26.43 \%$ to $38.73 \%$ and $32.53 \%$ to $42.50 \%$ respectively when the temperature was increased from $30^{\circ} \mathrm{C}$ to $45^{\circ} \mathrm{C}$. On increasing the temperature further to $60^{\circ} \mathrm{C}, 75^{\circ} \mathrm{C}$ and $90^{\circ} \mathrm{C}$, Ig-nZVI gave an elimination percentage of $55.13 \%, 76.20 \%$ and $94.20 \%$ while results obtained for nZVI were $53.60 \%, 69.93 \%$ and $78.61 \%$ respectively. Results obtained for the elimination of MO by Ig-nZVI at temperatures $30^{\circ} \mathrm{C}$ to $90^{\circ} \mathrm{C}$ increased from $23.53 \%$ to $79.50 \%$ while results for $\mathrm{nZVI}$ at the same temperature range, increased from $20.47 \%$ to $74.97 \%$ respectively. The improvement in the elimination of MR and MO could be attributed to a reduction in the viscosity of the dye solution so that the mass transfer resistance to the adsorbate in the boundary layer decreases. In addition, increase the rate of dispersion of adsorbate molecules in the inner pores of adsorbent particles (Wang and Zhu, 2007; Dada et al., 2015).

Equilibrium Isotherm Analysis: The relationship between the quantity of a substance adsorbed at constant temperature and its concentration in the aqueous solution is called the adsorption equilibrium isotherm. This isotherm is an excellent tool in 
establishing the most appropriate correlations of the equilibrium data of each system which may aid the optimization and design of an appropriate adsorption system to eliminate the dye. To relate the experimental data, two mono-component isotherm models; the Langmuir and Freundlich isotherm models were employed.

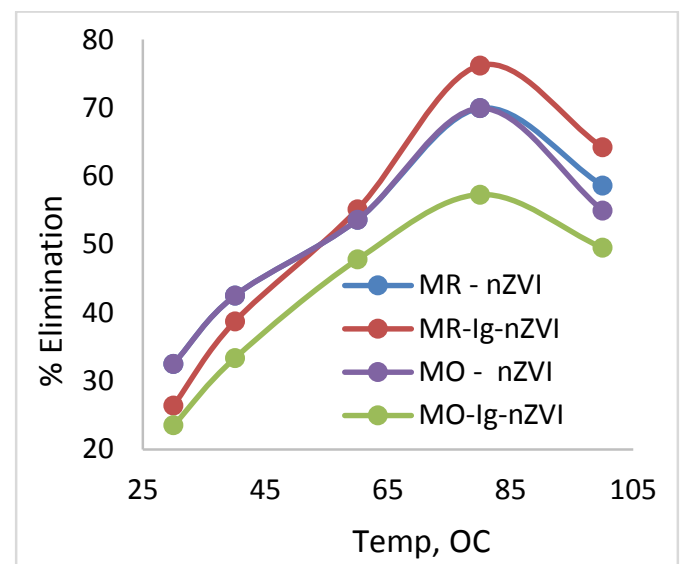

Fig 7: Effect of Temperature on elimination of MR with Ig-nZVI and nZVI.

Langmuir isotherm: The Langmuir adsorption isotherm model explains the variation of adsorption of adsorbates with concentration. It is based on the assumption that maximum adsorption occurs when a saturated monolayer of adsorbate molecules is present on the adsorbent surface, the energy of adsorption is constant, and there is no migration or interaction between the adsorbate molecules on the surface plane. The linear expression of the Langmuir isotherm model as expressed in equation 3 was used to obtain figure 8 .

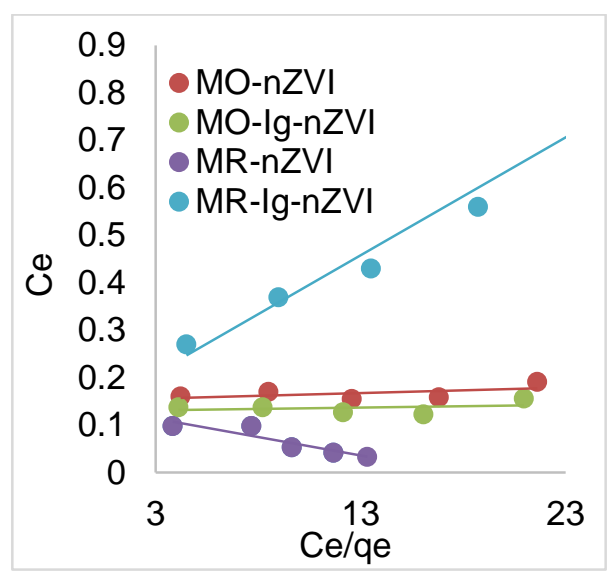

Fig 8: Langmiur isotherm of elimination of MR and MO by IgnZVI and nZVI

The Langmuir parameters obtained from Figures 8 are shown in Table 1. The elimination of MR by unstabilized (nZVI) and Irvingia gabonensis-iron oxide- stabilized (Ig-nZVI) nanocomposite materials reveals that the Langmuir equilibrium constant, $\mathrm{K}_{\mathrm{L}}(\mathrm{L} / \mathrm{mg})$ related to energy of adsorption which quantitatively reflects the affinity between the adsorbent and adsorbate were computed as 0.079 and 0.046 respectively with $\mathrm{R}^{2}$ values of 0.62 and 0.87 . Also, elimination of MO by un-stabilized (nZVI) and Irvingia gabonensis-iron oxide-stabilized (Ig-nZVI) nanocomposite had $\mathrm{K}_{\mathrm{L}}$ values of $0.057 \mathrm{~L} / \mathrm{mg}$ and $0.185 \mathrm{~L} / \mathrm{mg}$ respectively and an $\mathrm{R}^{2}$ value of 0.845 and 0.9598 respectively. These values implied that the elimination process of MR and MO by un-stabilized (nZVI) and Irvingia gabonensis-iron oxide-stabilized (Ig-nZVI) nanocomposite was both partially linear and perhaps may be unfavourable and the data did not fit well to the Langmuir isotherm model. Hence, it can be inferred that the capacity of un-stabilized (nZVI) and Irvingia gabonensis-iron oxide-stabilized (Ig-nZVI) nanocomposites to eliminate both $\mathrm{MR}$ and $\mathrm{MO}$ in aqueous system is low based on the Langmuir isotherm model.

Freundlich isotherm: The Freundlich isotherm explains that the extent of adsorption varies directly with pressure. This empirical relationship describes the multilayer adsorption of heterogeneous systems and assumes that different sites have several adsorption energies involved (Horsfall and Spiff, 2005). The linear model of the Freundlich isotherm was used to logarithmically express as the experimental data (Figure 9). The Freundlich constants which gives an idea of the adsorption intensity and capacity, respectively were computed and are presented in Table 1.

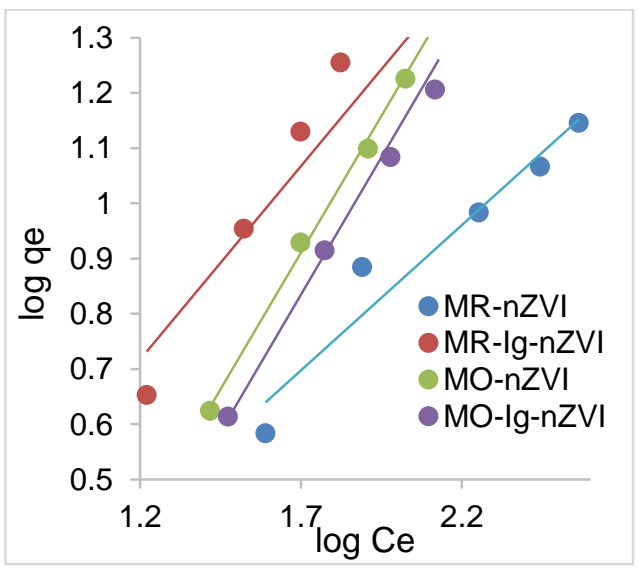

Fig 9: Freundlich isotherm of elimination of MR and MO by IgnZVI and nZVI

The results showed that, the degree of non-linearity between solution concentration and intensity of elimination depends on the heterogeneity which indicates the distribution of bonds and it is not 
dependent on the concentrations of adsorbents. The degree of non-linearity between solution concentration and adsorption depends on $n$ as follows: If $n=1$, the adsorption is linear; if $n<1$, this implies that the adsorption process is chemical; if $n>1$, the adsorption is a favorable physical process (Kumar et al., 2010; Shahbeig et al., 2013; Youssef et al., 2013). The investigation was carried out by the plot of $\log \mathrm{q}_{\mathrm{e}} \mathrm{vs}$ $\log C_{e}$ (Figure 9). The values from the plot are presented in Appendix IV. $\mathrm{K}_{\mathrm{f}}$ and $1 / \mathrm{n}$ was determined from the intercept and slope of the plot. The adsorption of MR onto Ig-nZVI and nZVI was favored by the Freundlich isotherm model with $\mathrm{n}$ values of 1.42 (Ig$\mathrm{nZVI}$ ) and 1.90 (nZVI) and $\mathrm{R}^{2}$ values of 0.89 and 0.94 for Ig-nZVI and nZVI respectively. The adsorption of MO onto Ig-nZVI and nZVI was also favored by the Freundlich isotherm model with $n$ values of 1.00 (Ig$\mathrm{nZVI}$ ) and 1.01 (nZVI) and $\mathrm{R}^{2}$ values of 0.98 and 0.99 for Ig-nZVI and nZVI respectively. The higher values of $\mathrm{n}$ and $\mathrm{R}^{2}$ for the adsorption of MR and MO onto IgnZVI and nZVI implied that the adsorption process was a favorable physical process. These values also indicate the affinity of MR and MO molecules for the nano-adsorbents (Ig-nZVI and nZVI). Hence it can be inferred that the adsorption of both MR and MO fitted well to the Freundlich isotherm model. A similar trend was observed by Shaibu et al. (2014).

Table 1. Elimination Equlibrium Isotherm parameters

\begin{tabular}{lllllll}
\hline $\begin{array}{l}\text { Adsorbate- } \\
\text { Adsorbents }\end{array}$ & \multicolumn{2}{l}{ Freundlich isotherms parameters } & \multicolumn{3}{l}{ Langmuir Isotherm parameters } \\
\cline { 2 - 7 } & $\begin{array}{l}\mathrm{K}_{\mathrm{f}} \\
(\mathrm{mg} / \mathrm{g})(\mathrm{L} / \mathrm{mg})^{1 / \mathrm{n}}\end{array}$ & $\mathrm{n}$ & $\mathrm{R}^{2}$ & $\begin{array}{l}\mathrm{q}_{\max } \\
(\mathrm{mg} / \mathrm{g}\end{array}$ & $\begin{array}{l}\mathrm{K}_{\mathrm{L}} \\
\mathrm{L} / \mathrm{mg})\end{array}$ & $\mathrm{R}^{2}$ \\
\hline MO-nZVI & 0.1397 & 1.006 & 0.9971 & 128.21 & 0.056849 & 0.845 \\
MO-Ig-nZVI & 0.1682 & 1.009 & 0.9792 & 40.02 & 0.184682 & 0.9598 \\
MR-nZVI & 0.6374 & 1.904 & 0.9413 & 83.35 & 0.07888 & 0.6231 \\
MR-Ig-nZVI & 0.7473 & 1.425 & 0.8927 & 166.7 & 0.046359 & 0.865 \\
\hline
\end{tabular}

Table 2. Comparison of maximum elimination capacities with respect to MR and MO in the present study with those reported in the

\begin{tabular}{|c|c|c|c|}
\hline \multirow{3}{*}{ Nano-composites } & \multirow{2}{*}{\multicolumn{2}{|c|}{$\begin{array}{l}\text { literature } \\
\mathbf{q}_{\max }, \mathbf{m g} / \mathbf{g}\end{array}$}} & \multirow{3}{*}{ Reference } \\
\hline & & & \\
\hline & MR & MO & \\
\hline CNT/Fe/CS composite & 125 & 142.9 & Jie et al., 2015 \\
\hline Cork Activated composite & - & 16.66 & Haitham et al., 2019 \\
\hline PANI/glass composite & 93 & 147 & Fouad and Benlahbib, 2015 \\
\hline KOH-Activated polypyrrole-based & 497.50 & 520.8 & Alghamdi et al., 2019 \\
\hline Chitosan/kaoli $/ \gamma-\mathrm{Fe}_{2} \mathrm{O}_{3}$ & 36.67 & 35.27 & Jiang et al., 2011 \\
\hline Activated Pomelo peel waste & 163.11 & 226.90 & Zhang et al., 2020 \\
\hline Potato peel powder & 30.48 & - & Enenebeaku et al., 2019 \\
\hline Phosphate Activated carbon & 226.90 & 435.25 & Equbal et al., 2018 \\
\hline Amidoxine composite & - & 142 & Nazia Rahman et al 2019 \\
\hline Water hyacinth biomass & 23.833 & - & Tarawou et al., 2007 \\
\hline (nZVI & 83.35 & 40.02 & This Study \\
\hline Ig-nZVI & 166.7 & 128.21 & This Study \\
\hline
\end{tabular}

Comparison of Adsorption Capacities with Literature Data: The adsorption capacities of un-stabilized (nZVI) and Irvingia gabonensis-iron oxide-stabilized (Ig-nZVI) nanocomposite materials as well as of other adsorbents with respect to methyl red and methyl orange reported in the literature are presented in Table I and are compared with those obtained for this study.

The ultimate adsorption capacities compared were those calculated from a Langmuir-type isotherm at 30 degrees and at an optimum solution $\mathrm{pH}$ of 8.0. It is palpable that the adsorption capacities vary within a wide range for the different adsorbents, depending on the experimental conditions. However, of unstabilized (nZVI) and Irvingia gabonensis-iron oxidestabilized (Ig-nZVI) nanocomposite materials were found to have strong potential regarding the removal of methyl red and methyl orange.
Adsorption Kinetics: Kinetic models were employed in this study to determine the mechanism of adsorption of MR and MO onto Ig-nZVI and nZVI. In order to investigate the controlling mechanism of adsorption processes such as mass transfer and chemical reaction, the pseudo-first-order and pseudo-second-order kinetic models were applied to model the kinetics of dye adsorption onto nZVI and Ig-nZVI. The rate constant, $\mathrm{k}_{\mathrm{ad}}$ and correlation coefficients for different dyes were computed from the linear plots of $\log \left(\mathrm{q}_{\mathrm{e}}-\right.$ $\mathrm{q}_{\mathrm{t}}$ ) versus $\mathrm{t}$ (Fig 9) and are listed in Table 3. The correlation coefficients for the pseudo-first-order kinetic model are low. Moreover, a large difference of equilibrium adsorption capacity $\left(\mathrm{q}_{\mathrm{e}}\right)$ between the experiment and calculation was observed, indicating a poor pseudo first-order fit to the experimental data. The result (Table 3C and Appendix V) showed that the data did not fit into the whole time of study range of pseudo first-order model which is in line with Sarat 
and Valdya (2016) findings in the study of adsorption kinetics mechanism of blue 222 reactive dyes onto $R$ arrhizus. This could be as a result of the external resistance or boundary layer giving rise to time lag (Ho \& McKay, 1999).

In order to apply the pseudo-second-order equation as expressed in equation 7 (Ho and McKay 1999)

$$
\frac{\mathrm{t}}{\mathrm{q}_{\mathrm{t}}}=\frac{1}{\mathrm{~h}}+\frac{1}{\mathrm{q}_{\mathrm{e}}} \mathrm{t}
$$

Showed that $\mathrm{h}=\mathrm{kq}_{\mathrm{e}}{ }^{2}\left(\mathrm{mg} \mathrm{g}^{-1} \mathrm{~min}^{-1}\right)$ can be regarded as the initial adsorption rate when $\mathrm{t} \rightarrow 0$ and $\mathrm{k}$ is the pseudo-second-order rate constant of adsorption ( $g$ $\mathrm{mg}^{-1} \mathrm{~min}^{-1}$ ). A plot of $\mathrm{t} / \mathrm{q}_{\mathrm{t}}$ versus $\mathrm{t}$ should give a straight line if pseudo-second-order kinetics are applicable and $\mathrm{q}_{\mathrm{e}}, \mathrm{k}$ and $\mathrm{h}$ can be determined from the slope and intercept of the plot, respectively. The plots of the linearized form of the pseudo-second-order reaction for the dues are shown in Fig. 10. The pseudo-firstorder and pseudo-second-order rate constants determined from Figs. 9 and 10 are presented in Table 3 , along with the corresponding correlation coefficients. The plot of $\mathrm{t} / \mathrm{q}_{\mathrm{t}}$ versus $\mathrm{t}$ for the pseudosecond-order model (Fig. 7) yields very good straight lines (correlation coefficient, $\mathrm{R}^{2}>0.99$ ) as compared to the pseudo-first order plot. The pseudo-second-order rate constants were in the range of 0.0088 to 0.0963 $\mathrm{g} / \mathrm{mg}$-min. The theoretical values of $\mathrm{q}_{\mathrm{e}}$ also agree very well with the experimental ones. Both facts suggest that the adsorption of the dyes by nZVI and Ig-nZVI follows the pseudo-second-order kinetic model, which relies on the assumption that chemisorption may be the rate-limiting step. In chemisorption, the metal ions stick to the adsorbent surface by forming a chemical (usually covalent) bond and tend to find sites that maximize their coordination number with the surface (Atkins, 1995). The pseudo-second-order kinetic analysis reveals that the value of the initial adsorption rates (h) increases with increase in the initial dye concentration. The lower the concentration of metal ions in the solution, the lower the probability of collisions between these species and, hence, the faster dye molecules can bond to the active sites on the surface of the adsorbent (Wong et al., 2003).

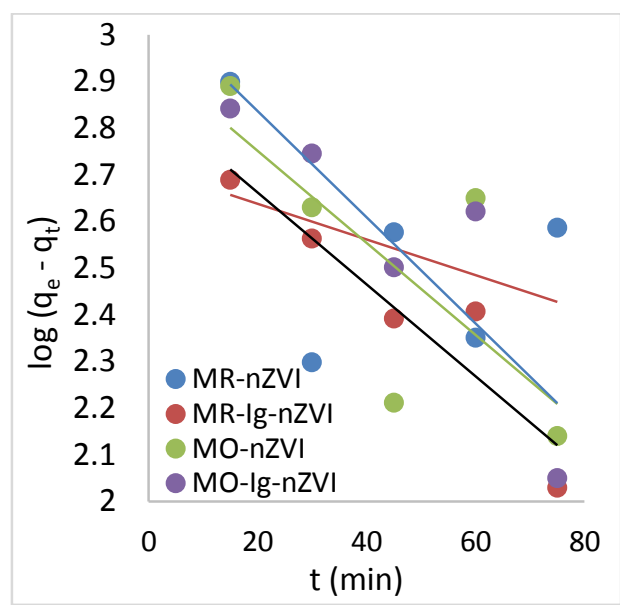

Fig 9: Pseudo-first-order kinetic plot for $\mathrm{MR}$ and $\mathrm{MO}$ elimination with nZVI and Ig-nZVI

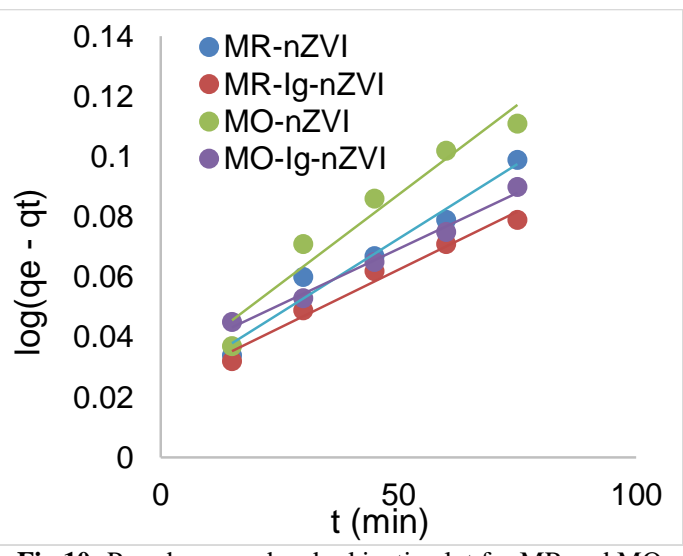

Fig 10: Pseudo-second-order kinetic plot for $M R$ and $M O$ elimination with nZVI and Ig-nZVI

Table 3 Kinetic parameters for elimination of MR and MO in aqueous solution by un-stabilized (nZVI) and Irvingia gabonensis-iron oxidestabilized (Ig-nZVI) nanocomposite materials

\begin{tabular}{|c|c|c|c|c|}
\hline \multirow[b]{2}{*}{ Adsorbent } & \multicolumn{2}{|c|}{ Pseudo first order } & \multicolumn{2}{|c|}{ Pseudo second order } \\
\hline & $\mathrm{k}_{1}\left(\min ^{-1}\right)$ & $\mathrm{R}^{2}$ & $\mathrm{k}_{2}\left(\mathrm{~g} / \mathrm{mg}^{-1} \mathrm{~min}^{-1}\right)$ & $\mathrm{R}^{2}$ \\
\hline MO-nZVI & 0.0228 & 0.5415 & 60168.47 & 0.942 \\
\hline MO-Ig-nZVI & 0.026254 & 0.7663 & 89285.71 & 0.9899 \\
\hline MR-nZVI & 0.008751 & 0.145 & 86580.09 & 0.9641 \\
\hline MR-Ig-nZVI & 0.022569 & 0.8841 & 105042 & 0.9742 \\
\hline
\end{tabular}

Table 4. Thermodynamic parameters () for the adsorption of MR and MO onto nZVI and nZVI

\begin{tabular}{llllll}
\hline Adsorbents & $\Delta \mathrm{G} \mathrm{kJ} / \mathrm{mol}$ & $\Delta \mathrm{H} \mathrm{kJ} / \mathrm{mol}$ & $\Delta \mathrm{S} \mathrm{kJ} / \mathrm{mol}$ & $\mathrm{Ea} \mathrm{kJ} / \mathrm{mol}$ & $\mathrm{R}>2$ \\
\hline MO-nZVI & -6.951 & -61.8797 & -45.6181 & -26.86917 & 0.953 \\
MO-Ig-nZVI & -5.341 & -84.02434 & -70.5055 & -36.48473 & 0.9485 \\
MR-nZVI & -5.529 & -85.60237 & -73.2091 & -37.16994 & 0.9838 \\
MR-Ig-nZVI & -5.961 & -88.74683 & -75.1813 & -38.53532 & 0.9858 \\
\hline
\end{tabular}


Thermodynamics Studies: In order to evaluate the feasibility of the elimination process, the thermodynamic and activation energy parameters such as free energy, enthalpy and entropy changes were calculated using equations $7,8,9,10$ and 11 . The data obtained from the effect of temperature on the adsorption of MR and MO onto Ig-nZVI and nZVI were tested with the adsorption thermodynamic equations. The thermodynamic parameters were determined from the Van't Hoff plot of 1/T versus log $\mathrm{q}_{\mathrm{e}} / \mathrm{C}_{\mathrm{e}}$. The standard enthalpy change $\Delta \mathrm{H}^{0}\left(\mathrm{~kJ} \mathrm{~mol}^{-1}\right)$ and standard entropy change $\Delta \mathrm{S}^{0}\left(\mathrm{~J} \mathrm{~mol}^{-1} \mathrm{~K}^{-1}\right)$ could be calculated from the slope and intercept of the plot with equations 10 (Boparai et al., 2010; Ayanda et al., 2013).

The elimination of MR and MO from aqueous media increased with an increase in temperature (Figures 4.11 and 4.12). This could be attributed to a reduction in the viscosity of the dye solution so that the mass transfer resistance to the adsorbate in the boundary layer decreases (Dada et al., 2015). A positive value of enthalpy change $\left(\Delta \mathrm{H}^{0}\right) 3.39 \mathrm{kJmol}^{-1}$ (Ig-nZVI) and $776.26 \mathrm{kJmol}^{-1}$ (nZVI) was obtained for the adsorption of MR onto Ig-nZVI and nZVI. A positive $\Delta \mathrm{H}^{0}$ showed that the adsorption of MR onto Ig-nZVI and nZVI were both endothermic (Figures 4.25 and 4.26). The standard entropy change $\left(\Delta \mathrm{S}^{0}\right)$ values of 131.35 $\mathrm{JKmol}^{-1}$ (Ig-nZVI) and $42.12 \mathrm{JKmol}^{-1}(\mathrm{nZVI})$ obtained for MR adsorption onto Ig-nZVI and nZVI indicated an increased degree of randomness at the solid-liquid interface during the adsorption of MR molecules onto Ig-nZVI and nZVI while the negative values of the standard Gibbs free energy $\left(\Delta \mathrm{G}^{0}\right), 5.95 \mathrm{KJmol}^{-1}$ and $12.0 \mathrm{KJmol}^{-1}$ indicated the feasibility and spontaneity of the adsorption process of MR onto Ig-nZVI and nZVI respectively.

Similarly, the positive $\Delta \mathrm{H}^{0}$ values of $31.707 \mathrm{kJmol}^{-1}$ and $20.908 \mathrm{kJmol}^{-1}$ for this study suggests that the adsorption of MO onto Ig-nZVI and nZVI respectively was endothermic (Figures 4.27 and 4.28). The standard entropy change $\left(\Delta \mathrm{S}^{0}\right), 124.169 \mathrm{JKmol}^{-1}(\mathrm{Ig}$ $\mathrm{nZVI}$ ) and $92.327 \mathrm{JKmol}^{-1}$ (nZVI) indicated an increased degree of randomness at the solid-liquid interface during the adsorption of MO molecules by the adsorbates while the negative values of the standard Gibbs free energy $\left(\Delta \mathrm{G}^{0}\right), 5.92 \mathrm{KJmol}^{-1}(\mathrm{Ig}$ nZVI) and $7.07 \mathrm{KJmol}^{-1}(\mathrm{nZVI})$ indicated the feasibility and spontaneity of the adsorption process of MO by Ig-nZVI and nZVI respectively. This result is similar to those reported by Hao et al. (2010) and Lisha et al. (2010).

Dye elimination was found to be associated with strong electrostatic forces (physisorption), the overall process being slightly endergonic $\left(\Delta \mathrm{G}^{0}>0\right)$. Our study shows that Ig-nZVI has a great potential of removing dyes from wastewater and other dye-polluted aquatic systems.

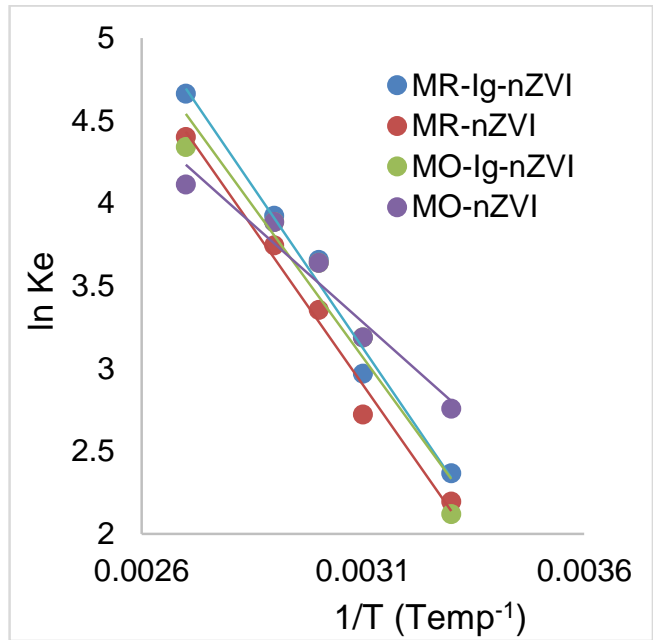

Fig 11: Thermodynamic plot for MR and MO elimination with nZVI and Ig-nZVI

Conclusion: Zerovalent iron nanoparticle and Irvingia gabonensis zerovalent iron nanoparticle were synthesized using sodium borohydride and Irvingia gabonensis aqueous leaves extract respectively. Both Ig-nZVI and nZVI eliminated methyl red and methyl orange from aqueous media but Ig-nZVI had better efficiency for removal of methyl red and methyl orange. This study has contributed to our knowledge on the utilization of nZVI and Ig-nZVI as an abundant, eco-friendly, low-cost alternative in the remediation of industrial effluents such as textile mill laden with organic dyes. Secondly, our knowledge on some of the functional groups present in Ig-nZVI, and nZVI has been shown. The various conditions of eliminating organic dyes from aqueous media using Ig-nZVI, and nZVI have established that nanocomposites are resourceful in the remediation of industrial effluents with organic dyes under these varying conditions. This has also added to our knowledge on how to employ these nano-adsorbents (Ig-nZVI, and nZVI) under varying conditions with respect to effluent treatment.

\section{REFERENCES}

Abbassian, K., Kargari, A; Kaghazchi, T. (2015). Phenol removal from aqueous solutions by a novel industrial solvent. Chemical Engineering Communications, 202(3), 408-413.

Abdulaziz Ali Alghamdi., Abdel-Basit Al-Odayni *, Waseem Sharaf Saeed *, Mohammed S. Almutairi, Fahad A. Alharthi, Taieb Aouak and Abdullah AlKahtani Adsorption of Azo Dye Methyl Orange from Aqueous Solutions Using Alkali-Activated 
Equilibrium, Kinetic and Thermodynamic Studies of Dyes.....

Polypyrrole-Based Graphene Oxide (2019). Molecules, 24(20), 3685

Abdulrahman, F; Inyang, I. S; Abbah, J; Binda, L; Amos, S and Gamaniel, K (2004). Effect of Aqueous Leaf Extract of Irvingia Gabonensis on Gastrointestinal Tract in Rodents. Indian Journal of Experimental Biology. 2(8):787-91.

Adeyemo, A. A., Adeoye, I. O., \& Bello, O. S. (2017). Adsorption of dyes using different types of clay: a review. Applied Water Science, 7(2), 543-568.

Adowei, A; Abia, A. A. (2016). Chemical Oxygen Demand (COD) Attenuation of Methyl Red in Water using Biocarbons obtained from Nipa Palm Leaves. J. Appl. Sci. Environ. Manage. 20 (4) 1163-1176

Bing Zhang, Yunhai Wu \& Ligen Cha (2020) Removal of methyl orange dye using activated biochar derived from pomelo peel wastes: performance, isotherm, and kinetic studies, Journal of Dispersion Science and Technology, 41:1, 125-136, DOI: 10.1080/01932691.2018.1561298

Chen, Y. M., Tsao, T. M., \& Wang, M. K. (2011). Removal of crystal violet and methylene blue from aqueous solution using soil nano-clays. In International conference on environment science and engineering, IPCBEE (Vol. 8, pp. 252-254).

Dada, A. O., Adekola, F. A., \& Odebunmi, E. O. (2015). A novel zerovalent manganese for removal of copper ions: synthesis, characterization and adsorption studies. Applied Water Science, 7(3), 1409-1427

Ebong, Sifon Emem, Adowei, Pereware, and Obuzor, Gloria Ukalina. (2020). Phytosynthesis and Characterization of Iron Nanocomposites by Irvingia Gabonensis (Ogbono) Aqueous and Ethanol Leaf Extracts. International Journal of Research $8(5), 256-265$.

Enenebeaku, Conrad K; Nnaemeka J. Okorocha, Uchechi E. Enenebeaku, Ikechukwu C. Ukaga (2017). , "Adsorption and Equilibrium Studies on the Removal of Methyl Red from Aqueous Solution Using White Potato Peel Powder", International Letters of Chemistry, Physics and Astronomy. 72. $52-64$

Equbal Ahmad Khan; Shahjahan Tabrez; Alam Khan (2018). Adsorption of methyl red on activated carbon derived from custard apple (Annona squamosa) fruit shell: Equilibrium isotherm and kinetic studies. Journal of Molecular Liquids. 249 (1) $1195-1211$
Fouad Krika \& Omar el Farouk Benlahbib (2015) Removal of methyl orange from aqueous solution via adsorption on cork as a natural and low-coast adsorbent: equilibrium, kinetic and thermodynamic study of removal process, Desalination and Water Treatment, 53:13, 3711-3723,

Gil, A., Assis, F. C. C., Albeniz, S., \& Korili, S. A. (2011). Removal of dyes from wastewaters by adsorption on pillared clays. Chemical Engineering Journal, 168(3), 1032-1040.

Gomes, A. C., Fernandes, L. R., \& Simões, R. M. (2012). Oxidation rates of two textile dyes by ozone: effect of $\mathrm{pH}$ and competitive kinetics. Chemical engineering journal, 189, 175-181.

Guo, Z., Ma, R., \& Li, G. (2006). Degradation of phenol by nanomaterial $\mathrm{TiO}_{2}$ in wastewater. Chemical engineering journal, 119(1), 55-59.

Gürses, A., Doğar, Ç, Yalçın, M., Açıkyıldız, M., Bayrak, R., \& Karaca, S. (2006). The adsorption kinetics of the cationic dye, methylene blue, onto clay. Journal of Hazardous Materials, 131(1), 217-228.

Haitham, K; S. Razak, M. A. Nawi (2019). Kinetics and isotherm studies of methyl orange adsorption by a highly recyclable immobilized polyaniline on a glass plate. Arabian Journal of Chemistry. Volume 12, Issue 7, November 2019, Pages 1595-1606

Horsfall, M. Jnr and Spiff, A. I. (2005). Distribution of Trace Metals and Fulvic Acids in Sediments of the New Calabar River, Port Harcourt, Nigeria. Asian Journal of Water, Environment \& Pollution; pg. 75 -79 .

Horsfall, M. Jnr.; and Spiff, A. I. (2005). Sorption of Lead, Cadmium, and Zinc on Sulfur-Containing Chemically Modified Wastes of Fluted Pumpkin (Telfaria occidentalis) HOOK f.). Chem. \& Biodiversity; Vol. 2; pp $373-385$.

Jiang, R; Zhu, H. and Yongqian Fu (2011), "Equilibrium and Kinetic studies on adsorption of methyl orange from aqueous solution on chitosan $/ \mathrm{kaolin} / \gamma$-Fe2O3 nanocomposite," 2011 International Conference on Remote Sensing, Environment and Transportation Engineering, Nanjing, 2011, pp. 7565-7568, doi: 10.1109/RSETE.2011.5966122.

Jie Ma; Yuan Zhuang; and Fei Yu (2015). Equilibrium, kinetic and thermodynamic adsorption studies of organic pollutants from aqueous solution onto CNT/C@Fe/chitosan composites. New Journal of Chemistry. 12: 9035 - 9986 
Kant, R (2012). Textile dyeing industry and environmental hazard. Natural Science. 4. (1): 2226.

Karima, B., Mossab, B. L., \& A-Hassen, M. E. N. I. A. I. (2010). Removal of methylene blue from aqueous solutions using an acid activated Algerian bentonite: equilibrium and kinetic studies. In International renewable energy congress (pp. 1-8).

Li, S. (2010). Removal of crystal violet from aqueous solution by sorption into semi-interpenetrated networks hydrogels constituted of poly (acrylic acidacrylamide-methacrylate) and amylose. Bioresource technology, 101(7), 2197-2202.

Lin, C. J., Lo, S. L., \& Liou, Y. H. (2005). Degradation of aqueous carbon tetrachloride by nanoscale zerovalent copper on a cation resin. Chemosphere, 59(9), 1299-1307.

Lin, S. H., Juang, R. S., \& Wang, Y. H. (2004). Adsorption of acid dye from water onto pristine and acid-activated clays in fixed beds. J. Hazardous Mat. 113(1), 195-200.

Liu, T., Zhao, L., Sun, D., \& Tan, X. (2010). Entrapment of nanoscale zero-valent iron in chitosan beads for hexavalent chromium removal from wastewater. $J$. Hazardous Mat. 184(1), 724-730.

Liu, Z., \& Zhang, F. S. (2010). Nano-zerovalent iron contained porous carbons developed from waste biomass for the adsorption and dechlorination of PCBs. Bioresource technology, 101(7), 2562-2564.

Mandal, D., Bolander, M. E., Mukhopadhyay, D., Sarkar, G., \& Mukherjee, P. (2006). The use of microorganisms for the formation of metal nanoparticles and their application. Appl. Microbiol. Bbiotechn. 69(5), 485-492.

Meshko, V., Markovska, L., Mincheva, M., \& Rodrigues, A. E. (2001). Adsorption of basic dyes on granular acivated carbon and natural zeolite. Water research, 35(14), 3357-3366.

Mgbemena, Nkoli Marynnn; Ilechukwu, Ifenna; Okwunodolu, Felicia Uchechukwu; Chukwurah, Joe-Vera, Ogugua and Lucky, Isioma Blessing (2019). Chemical composition, proximate and phytochemical analysis of Irvingia gabonensis and Irvingia wombolu peels, seed coat, leaves and seeds. Ovidius University Annals of Chemistry. 30 (1): 65 - 69, 2019

Mittal, A. K., Chisti, Y., \& Banerjee, U. C. (2013). Synthesis of metallic nanoparticles using plant extracts. Biotechnology advances, 31(2), 346-356.
Namasivayam, C., \& Arasi, D. J. S. E. (1997). Removal of congo red from wastewater by adsorption onto waste red mud. Chemosphere, 34(2), 401-417.

Namasivayam, C., \& Yamuna, R. T. (1992). Removal of congo red from aqueous solutions by biogas waste slurry. Journal of Chemical Technology and Biotechnology, 53(2), 153-157.

Nazia Rahman, Nirmal Chandra Dafader, Abdur Rahim Miah \& S. Shahnaz (2019) Efficient removal of methyl orange from aqueous solution using amidoxime adsorbent, International Journal of Environmental Studies, 76:4, 594-60

Ngondi, J. L., Oben, J. E., \& Minka, S. R. (2005). The effect of Irvingia gabonensis seeds on body weight and blood lipids of obese subjects in Cameroon. Lipids in health and Disease, 4(1), 1220

Oben, J. E. (2011). Seed Extract of the West African Bush Mango (Irvingia Gabonensis) and its Use in Health. Nuts and Seeds in Health and Disease Prevention pp. 1187-1189 https://doi.org/10.1016/B978-0-12-375688$\underline{6.10140-9}$

Okogun, Joseph I. (2002). Drug discovery through ethnobotany in Nigeria: some results. Advances in Phytomedicine. 1. 145-154

Phenrat, T., Saleh, N., Sirk, K., Tilton, R. D., \& Lowry, G. V. (2007). Aggregation and sedimentation of aqueous nanoscale zerovalent iron dispersions. Environ. Sci. Techn. 41(1), 284-290.

Ponder, S. M., Darab, J. G., \& Mallouk, T. E. (2000). Remediation of $\mathrm{Cr}$ (VI) and $\mathrm{Pb}$ (II) aqueous solutions using supported, nanoscale zero-valent iron. Environ. Sci. Tech. 34(12), 2564-2569.

Popli, S., \& Patel, U. D. (2015). Destruction of azo dyes by anaerobic-aerobic sequential biological treatment: a review. Inter. J. Environ. Sci. Tech. 12(1), 405-420.

Preethi, S., Sivasamy, A., Sivanesan, S., Ramamurthi, V., \& Swaminathan, G. (2006). Removal of safranin basic dye from aqueous solutions by adsorption onto corncob activated carbon. Ind. Chem. Res. 45(22), 7627-7632.

Purkait, M. K., Maiti, A., DasGupta, S., \& De, S. (2007). Removal of congo red using activated carbon and its regeneration. J. Hazardous Mat. 145(1), 287-295.

Saif, S., Tahir, A., \& Chen, Y. (2016). Green synthesis of iron nanoparticles and their environmental 
applications and implications. Nanomaterials, 6(11), 209.

Sayyad, A. S., Balakrishnan, K., Ci, L., Kabbani, A. T., Vajtai, R., \& Ajayan, P. M. (2012). Synthesis of iron nanoparticles from hemoglobin and myoglobin. Nanotechnology, 23(5), 055602.

Shaibu, S. E., Adekola, F. A., Adegoke, H. I., \& Ayanda, O. S. (2014). A comparative study of the adsorption of methylene blue onto synthesized nanoscale zerovalent iron-bamboo and manganese-bamboo composites. Materials, 7(6), 4493-4507.

Siskova, K. M., Straska, J., Krizek, M., Tucek, J., Machala, L., \& Zboril, R. (2013). Formation of zerovalent iron nanoparticles mediated by amino acids. Procedia Environ. Sci. 18, 809-817.

Szyguła, A., Guibal, E., Palacín, M. A., Ruiz, M., \& Sastre, A. M. (2009). Removal of an anionic dye (Acid Blue 92) by coagulation-flocculation using chitosan. J. Environ. Manage. 90 (10), 2979-2986.

Tarawou, T. and Horsfall, M. Jnr (2007). Adsorption of Methylene Blue Dye on Pure and Carbonized Water Weeds. Bioremediation J 11.2,1-8.

Tarawou, T; Horsfall, M. Jnr and Vicente, J L (2007). Adsorption of Methyl Red using Water hyacinth (Eichornia crassipes) Biomass. Chemistry \& Biodiversity $42236-2245$.

Vijayaraghavan, K. \& Yun, Y.S. (2008). Bacterial biosorbents and biosorption.Biotechnol. Adv.26, 266-291.

Virkutyte, J., \& Varma, R. S. (2013). Green synthesis of nanomaterials: environmental aspects. In Sustainable nanotechnology and the environment: advances and achievements (pp. 11-39). American Chemical Society.
Wang, L. (2009). Aqueous organic dye discoloration induced by contact glow discharge electrolysis. $J$. Hazardous Mat. 171(1), 577-581.

Wang, Q., Qian, H., Yang, Y., Zhang, Z., Naman, C., \& $\mathrm{Xu}, \mathrm{X}$. (2010). Reduction of hexavalent chromium by carboxymethyl cellulose-stabilized zero-valent iron nanoparticles. J. Contaminant hydrology, 114(1), 35-42.

Wang, S., \& Zhu, Z. H. (2007). Effects of acidic treatment of activated carbons on dye adsorption. Dyes and Pigments, 75(2), 306-314.

Wu, S. J., Liou, T. H., \& Mi, F. L. (2009). Synthesis of zero-valent copper-chitosan nanocomposites and their application for treatment of hexavalent chromium. Bioresource Tech. 100(19), 4348-4353.

Xiong, Z., Zhao, D., \& Pan, G. (2007). Rapid and complete destruction of perchlorate in water and ionexchange brine using stabilized zero-valent iron nanoparticles. Water Res. 41(15), 3497-3505.

Xu, F. L., Jorgensen, S. E., Shimizu, Y., \& Silow, E. (2013). Persistent organic pollutants in fresh water ecosystems. Sci. World J. 2013.

Xu, X., Wang, Q., Choi, H. C., \& Kim, Y. H. (2010). Encapsulation of iron nanoparticles with PVP nanofibrous membranes to maintain their catalytic activity. J. Membrane Sci. 348(1), 231-237.

Zawani, Z., Chuah, A. L., \& Choong, T. S. Y. (2009). Equilibrium, kinetics and thermodynamic studies: adsorption of Remazol Black 5 on the palm kernel shell activated carbon. Europ. J Sci. Res. 37(1), 6776.

Zhu, M. X., Lee, L., Wang, H. H., \& Wang, Z. (2007). Removal of an anionic dye by adsorption/precipitation processes using alkaline white mud. J. Hazardous Mat. 149(3), 735-741. 